\begin{abstract}
MS41 P13
Mechanical properties and structure of nanoporous and bulk borosilicate glass. I.P.Shakhverdova ${ }^{a}$, P.Paufler $^{\mathrm{a}}$, S.K.Filatov ${ }^{\mathrm{b}}$, R.S.Bubnova ${ }^{\mathrm{c}}$, M.Reibold ${ }^{\mathrm{a}}$, J.M.Feldkamp ${ }^{\mathrm{a}}$, C.G.Schroer ${ }^{\mathrm{a}}$, B.Müller ${ }^{\mathrm{d}}$, A.A.Levin ${ }^{\mathrm{a}}$, D.C.Meyer ${ }^{\mathrm{a}}$, ${ }^{\mathrm{a}}$ Inst.Strukturphysik, TU Dresden; ${ }^{b}$ Dpt. Crystallography, St. Petersburg State Univ., ${ }^{c}$ Inst. Silicate Chem.RAS, St. Petersburg; ${ }^{d}$ Inst. Phys. Chemie, Friedrich - Schiller-Univ. Jena, Germany

E-mail: paufler@physik.tu-dresden.de
\end{abstract}

Keywords: Porous glass, sodium borosilicate, hardness

Mechanical properties of bulk (BG) $18.1 \mathrm{Na}_{2} \mathrm{O} \cdot 16.9 \mathrm{~B}_{2} \mathrm{O}_{3} \cdot 65 \mathrm{SiO}_{2}(\mathrm{~mol} . \%)$ and nanoporous (NPG) $0.2 \mathrm{Na}_{2} \mathrm{O} \cdot 3.8 \mathrm{~B}_{2} \mathrm{O}_{3} \cdot 96 \mathrm{SiO}_{2} \quad(\mathrm{~mol} . \%) \quad$ sodium borosilicate glass were investigated by nano$\left(\right.$ TriboScope ${ }^{\mathrm{TM}}$ ) and microindentation (Shimatsu $H M V 2000)$. The nano- $(H)$ and microhardness $\left(H_{M}\right)$ as well as Young's moduli of NPG and BG were different. While both $H$ and $H_{M}$ varied between $\sim 10$ and $\sim 7 \mathrm{GPa}$ for the BG, values for NPG were an order of magnitude lower $(\sim 0.5 \mathrm{GPa})$. Young's moduli were detected of $\sim 82$ $\mathrm{GPa}$ and $\sim 5 \mathrm{GPa}$ for $\mathrm{BG}$ and NPG, respectively [1]. Additionally, cracks around the indent have been observed during the microindentation of $\mathrm{BG}$, whereas none of them could be detected in NPG. From the length of cracks of BG, the fracture toughness $K_{\mathrm{c}} \sim 1.67-1.94$ $\mathrm{MPa} \mathrm{m}^{1 / 2}$ was estimated following the procedure described in [2]. The structure of glasses was investigated by X-ray powder diffraction $\left(\mathrm{Cu}-K_{\alpha}\right.$ and $\mathrm{Mo}-K_{\alpha}$ radiation). For both glasses correlation distances of shortrange order were found close to those of crystalline compounds with similar chemical composition (quartz, tridymite, cristobalite). However, no significant difference in the structures of BG and NPG could be detected. So, we can conclude, that the difference in mechanical properties is basically affected by the absence of porosity in BG. Morphology of pores and their distribution were investigated by $\mu$-SAXS tomography (HASYLAB beamline BW4) [3] and transmission electron microscopy (FEI TECNAI F20/Cs-corrected TEM). According to the TEM study, the pores are of $\sim 20$ nm size.

Financial support by the Deutsche Forschungsgemeinschaft (DFG, Project Pa 451/23) and Russian Foundation for Basic Research (RFBR, 05-03-04002) is gratefully acknowledged.

[1] Paufler,P., Filatov,S.K., Shakhverdova,I.P., Bubnova,R.S. , Reibold, M., Müller,B. , Levin,A.A., Meyer,D.C., Glass Phys. Chem. 2007, 33, N3, accepted.

[2] Watanabe,T. et al., J. Mater. Sc. 2001, 36, 2427.

[3] Feldkamp, J. M. , Kuhlmann, M., Schroer, C.G., Roth, S. V., Timmann, A., Gehrke, R., Paufler, P. HASYLAB Annual Reports 2006, in press.

\section{MS41 P14}

$\mathrm{Al} / \mathrm{Si}$ and $\mathrm{Ca} / \mathrm{Eu}$ short range order in $\mathrm{Ca} / \mathrm{Eu}$ bicchulite, studied by FTIR spectroscopy. Nouri-Said $\underline{\text { Rahmoun }}^{a}$, Lars Peters ${ }^{b}$, Karsten Knorr ${ }^{a}$, Wulf Depmeier ${ }^{a}$, ${ }^{a}$ Institut of Geosciences, University Kiel, Germany, ${ }^{b}$ Chemistry Department University of Durham, UK. E-mail: nsr@min.uni-kiel.de

Keywords: FTIR spectroscopy, sodalites, short-range order
Recently, Al-rich alumino silicates of the solid solution series $\left|\mathrm{Ca}_{4+x} \mathrm{Eu}_{4-x}(\mathrm{OH})_{8}\right|\left[\mathrm{Al}_{12-x} \mathrm{Si}_{x} \mathrm{O}_{24}\right]-\mathrm{SOD}, 0 \leq x \leq 4$, were synthesised and the structures were characterised by X-ray diffraction and ${ }^{27} \mathrm{Al}$ MAS NMR [1]. The crystal structure corresponds to that of the mineral bicchulite, $\left|\mathrm{Ca}_{8}(\mathrm{OH})_{8}\right|\left[\mathrm{Al}_{8} \mathrm{Si}_{4} \mathrm{O}_{24}\right]$. Hetero-cubane like $\mathrm{Ca}_{4}(\mathrm{OH})_{4}$ clusters are located in the cages of this sodalite (SOD)type framework [2,3], formed by all-corner connected $\mathrm{SiO}_{4}$ and $\mathrm{AlO}_{4}$ tetrahedra. In the structure refinements $\mathrm{Al} / \mathrm{Si}$ and $\mathrm{Eu} / \mathrm{Ca}$ were assumed to be distributed statistically. However, broadening of ${ }^{27} \mathrm{Al}$ NMR resonance lines in Al-rich samples [1] pointed towards local order that could not be further specified. Here, powder infrared spectra of the samples synthesised and investigated by [1] were measured at room temperature with a Fourier transform spectrometer Bruker IFSS/66v, in order to further study local structural effects related to the cosubstitution of $\mathrm{Al}$ for $\mathrm{Si}$ and $\mathrm{Eu}$ for $\mathrm{Ca}$.

Spectra taken in the hydroxyl region yield information related to the local structural states of the hetero-cubane like clusters. Three different short range order patterns could be identified. Depending on $x$, different concentrations of $\mathrm{Ca}_{4}(\mathrm{OH})_{4}, \quad \mathrm{EuCa}_{3}(\mathrm{OH})_{4}, \quad$ and $\mathrm{Eu}_{2} \mathrm{Ca}_{2}(\mathrm{OH})_{4}$ clusters are found, whereas $\mathrm{Eu}_{3} \mathrm{Ca}(\mathrm{OH})_{4}$ or $\mathrm{Eu}_{4}(\mathrm{OH})_{4}$ clusters are not observed. Hence, short range order is maintained such that each SOD cage of an allalumina framework contains two $\mathrm{Ca}$ and two $\mathrm{Eu}$ per cluster.

The framework absorption bands ( 1400 to $350 \mathrm{~cm}^{-1}$ ) of the solid solution series can be grouped into three sets: Asymmetric stretching $v_{\mathrm{as}}(\mathrm{T}-\mathrm{O}-\mathrm{T})$, symmetric, stretching $v_{\mathrm{s}}(\mathrm{T}-\mathrm{O}-\mathrm{T})$ and bending modes $\delta(\mathrm{O}-\mathrm{T}-\mathrm{O})$, where $\mathrm{T}$ represent tetrahedrally coordinated $\mathrm{Si}$ or Al. The positions of the different modes shift linearly towards lower wave numbers for increasing $\mathrm{Al}$ content. The shifts are correlated with the change of the tetrahedra angles vs. the cell parameter [1]. Furthermore, Al-rich samples show a splitting of the bending mode. This is interpreted as the additional change of the local environment of $\mathrm{Al}$ due to the co-substitution of $\mathrm{Eu}^{3+}$ for $\mathrm{Ca}^{2+}$. Finally, changes in the line shape, resulting from cation ordering, are studied by autocorrelation analysis. In particular, samples of intermediate composition of the solid solution series have the highest values of the line broadening parameter, corr, suggesting that they are characterised by a relatively high degree of local structural heterogeneity.

Acknowledgement: This work was supported by the German Science Foundation, DFG, under contract De 412/31-1.

[1] Peters L.; Knorr, K.; Fechtelkord, M.; Appel, P.; Depmeier, W. Z. Kristallogr. 2006, 221, 643-648

[2] Pauling, L. Z. Kristallogr. 1930, 74, 213-225

[3] Sahl, K. Z. Kristallogr. 1980, 152, 13-21.

\section{MS41 P15}

Polytypism in micas from Black Hill and apparent polytypism in micas from Alto Paranaibo.

E. Mesto ${ }^{\mathrm{a}}, \mathrm{F}$. Scordari ${ }^{\mathrm{a}}$ a Dipartimento Geomineralogico,

Università degli Studi di Bari.

E-mail: f.scordari@geomin.uniba.it

\section{Keywords: Trioctahedral micas, polytypism, twinning.}

Micas are commonly found minerals of igneous and metamorphic rocks which form in a wide range of chemical and physical conditions. This particular feature 